\title{
WEAVING, SEWING AND PATCHING THE WORLD TOGETHER IN TWO CONTEMPORARY INDIAN NOVELS
}

\author{
Adrian OȚOIU*
}

\begin{abstract}
The image of political- and sectarian-torn India under Indira Gandhi's State of Emergency is countered by powerful metaphors of binding and union inspired by the subcontinent's millenial history of cloth-making. In Amitav Ghosh's debut novel The Circle of Reason, the old art of buti weaving becomes alternatively a sign of the new Mechanical Man and his ability to do or undo a fragmented India, and that of Art, that can create its own words and realities. Conversely, in Rohinton Mistry award-winning A Fine Balance, the havoc wrought in people's lives by the Emergency might seem to discard them like unwanted scraps of cloth, and yet the playful art of quiltmaking becomes a metaphor for the individuals' solution of joining their destinies in a meaningful patchwork.
\end{abstract}

Keywords: Indian fiction, the Emergency, text and texture, weaving, sewing, quilt, textile metaphor

\section{Man at the loom}

When Alu, a 12-year old Indian boy and polyglot prodigy, starts skipping classes to spend hours on end watching a weaver working at his loom, the people in his village are surprised. And their surprise turns to shock when the boy's adoptive father, Balaram, a teacher at the local school, decides that the promising yet "impassive" young boy should abandon school altogether and become an apprentice to Shombhu Debnath, the weaver. Balaram's friend Gopal sums up the shock as the "disbelief at the thought of an educated, literate man pushing his nephew to manual labour." (54). And Bhudeb-Roy, the school principal, fears that this perplexing decision might harm both the teacher's and the school's reputation, as nobody "will want to send their children to a school where they will be taught by a man who has apprenticed his own nephew to a weaver." (Ghosh 62)

This apparently whimsical decision is one of the many radical twists in the plot of The Circle of Reason, the celebrated debut novel of Amitav Ghosh, an author who went on to produce some of the most ambitious novels in contemporary Indian fiction, such as his Ibis trilogy on East India

\footnotetext{
* Assistant Professor PhD, Technical University of Cluj-Napoca, Faculty of Letters, 76 Victoriei Street, Baia Mare (adrian.otoiu@cunbm.utcluj.ro).
} 
Company's opium trade (2008-2015) or his epic of the Burmese war, The Glass Palace (2000).

However, radical as it might seem, Balaram's decision is anything but the result of a whim, anything but arbitrary. The present teacher at the rural school in Eastern India had a scientific formation and as a science reporter for a newspaper in Calcutta had even met Marie Jolliot-Curie on her trip to India. Part of Balaram's decision is based on the (mis)application of a scientific - or rather pseudoscientific - theory. A stern believer is the now discarded ideas of phrenology, the teacher tried to explain Alu's impassibility and apparent lack of emotivity through the arcane study of the bumps on his potato-shaped skull. In doing so he skipped the more probable hypothesis (formulated by his friend Gopal) of the orphan boy's mute suffering from the trauma of losing his parents, and went instead for the revelations brought about by his cranial bumps, where the alleged emergence of the "organ" of Combativeness alongside that of Mechanical Sense seemed to foreordain the boy for the tedious life of a weaver.

Balaram's perfunctory application of phrenology brushes aside Alu's proven intellectual gifts (for reading and foreign languages) and uses instead mere physical measurements to prove that he is tailored to become a weaver: "Alu's body, his hands, his legs, his arms... correspond exactly to his calculations of the proportions ideal for a weaver." (Ghosh 55). Unable to provide emotional support to his nephew, estranged from his wife, bullied by his principal, finding refuge in his impractical hobby-horse, Balaram has eventually found a purely mechanical cure to the orphan boy's melancholy. He even sings a paean to the loom, as the creator of this new Man, the Mechanical man:

"Man at the loom is the finest example of Mechanical man, a creature who makes his own world as no other can, with his mind. The machine is man's curse and his salvation, and no machine has created man as much as the loom." (55)

It should be said now that the mechanical causality of phrenology was just one of Balaram's motives in pushing his nephew to take weaving. The second - and deeper - motive has to do with the teacher's affilliation to an association called the Society for the Dissemination of Science and Rationalism among the People of Hindoostan or, simply, the Rationalists. Balaram, who had won over Gopal the presidency of the association, believed that an unfaltering appeal to Reason should cure many of India's ills. Unlike Gopal, who was all for grand abstract principles and ungraspable truths (such as his suggestion that the Cosmic boson, the elementary particle hypothethised by Indian researcher Sayten Bose, should be celebrated in chants to replace the worship of Hindu gods), Balaram thought that Reason should be brought into the most mundane aspects of the Indians' lives. It 
was this pragmatic atttitude that had actually earned him the presidency of the Rationalists' society.

The Rationalists' practical philosophy seems to be a reenactment of the ideas of the Enlightenment, adapted to the Indian society of the postcolonial years (the year is 1969, just before the Pakistano-Pakistani war of 1971). Education emphasizing the acquisition of practical skills, public health and hygiene are the main goals. These goals are to be reached through grassroots campaigns, that seem to be of limited - if not even ridiculous - scope, such as a Campagin for Clean Couts, under the slogan "Keep your underwear clean." Such apparently modest grassroots actions are in stark contrast with the offical campaigns bombastically promoted by politicians, such as the construction of a road to connect the village square to the house of teacher-turned-politician Bhudeb-Roy.

Initiated about the time when the rumble of the impending war is heard in the background, Balaram's most ambitious campaign is the launching of a new school for the masses, called the Pasteur School of Reason. This school is meant to not only replace the old school, that burned out when a blazing war plane crashed on it, but also to reach out to the whole community and offer both theoretical and practical skills, much needed by the low-skilled or unemployed population of the village. The curricula of the practical branch of this school is of particular interest to our present observations: there is one course of weaving, taught by the odd master weaver Shombhu Debnath, one course of tailoring taught by Torudebi (Balaram's wife), and one course in cloth marketing, taught by Rakhal the weaver's intrepid son. All courses orbit around cloth- and clothesmaking, which will prove to be quite profitable in the school's brief existence. All this might remind us of Mahatma Ghandi's insistence on the revival of traditional Indian cloth-making crafts (and the now iconic images of Ghandiji spinning the yarn alongside the women). However, this takes place more than twenty years since Ghandi's example, and the technology has been now updated. The tailors use sewing machines, the looms are partly mechanical, new patterns have emerged. All this represents, in Balaram's words, "simple and beautiful knowledge, coupled with labour... labour of a kind which represents the highest achievement of practical reason," thus making the school "the perfect embodiment of, the essence of Reason." (109)

Given this noble premise, the outcome of the school will be one riddled with perverse irony. Even if the cloth produced in the School of Reason eventually brings a fair profit, this is not used, as initially planned, in order to alleviate the lives of the unemployed, but to buy industrial quantities of carbolic acid, a strong disinfectant, that is to be sprayed all over the community. The hitherto perfectly rational Balaram has given way to irrational germophobia, that seems to be a form of Obsessive Compulsive 
Disorder. Trodden by incessant waves of refugees, replete with litter, infested with germs, the village of Lalpukur also suffers from another (ab)noxious invasion, that of populist demagogy, as embodied by the teacher-turned-politician Bhudeb-Roy. The old bully has in the meanwhile acquired financial power and now seeks election in a public position, using the local thugs to pave his way to power. In a fitting metaphor, this way becomes a projected paved road from the village square to Bhudeb's own house (which he sells to his gullible public as "the straight road to progress"). The road is thus planned so as to cross the land occupied by the not-so-legally erected premises of The School of Reason, which gives Bhudeb-Roy the pretext to file complaint after complaint with the police. A failed attempt at demolishing the school is the spark that starts an open conflict between the former colleagues.

While Balaram resists the siege, he pictures himself as a hero putting up a last-ditch resistance to the filth that has flooded the village. When his followers want to know where to start their sanitizing campaign, he directs them

"To the banyan tree, said Balaram. There's no part of the village more littered with filth." (119)

The banyan tree marks the centre of the village, where political rallies are held. Balaram's directions are therefore unambiguous: the filthiest place of the village - as that of India itself - is its centre of power. Filth thus becomes the epitome of India's historical diseases: political corruption, injustice and social inequality.

Thus, the hero who had started a grassroots campaign of public hygiene, aiming at reasonably modest targets, went on to jump at exceedingly large issues that were far beyond the reach of Practical Reason. Curing India's sectarian divisions, its lack of education and it rampant corruption were goals beyond the grasp of a mere country teacher.

And what had started as a burlesque misapplication of means Shombhu Debnath's and Balaram's discharging of a squirt-gun of disinfectant over an abject politician - will eventually end in disaster. In an epic backlash, filth strikes back at the Rationalists and kills them all, including Balaram. At the end of the first 150 pages of this long novel, the protagonist who seemed to be its center of meaning is now dead. Bereft of what seemed to be its backbone, the rest of the novel's cast will take a long time to recover its balance. This is but the the first major narrative jolt that Amitav Ghosh causes his massive narrative engine to nearly grind to a halt. The novel will start anew, in a new place, with an almost completely new set of characters, pushed haphazardly towards some other (apparently) rational goal. 


\section{In pursuit of Beauty}

Since the apparent protagonist of the novels' second and third sections is Alu, the polyglot boy turned weaver, we need to return to his apprenticeship. Strangely enough, despite everyone's misgivings, the boy not only seems unaffected by his weaning from books and linguistics, but he seems to thrive in the weaver's room. Overtly abandoned and despised by the grumpy weaver master, Alu bears stoically the low level stages of apprenticeship (starching yarn, winding bobbins, disentangling and threading the yarn, warping..), he endures the occasional beatings.

However, before even being allowed to sit at the loom, the boy is forced to learn by heart all the loom's lexicon in several languages: "Tangail words, stewed with Noakhali words, salted with Naboganj words, boiled up with English" (73).

The scene seems reminiscent of the Derridean notion of text as texture, or of Julia Kristeva's representation of text as intertext(ure). Indeed the boy has to thoroughly master all the text of cloth-making before he is allowed to move to the process of textile-making itself.

At this point we begin to understand why weaving has a completely different meaning for Alu than it had for his uncle. While for Balaram weaving was threading man and history together, or man and machinery together, for Alu the textile vocabulary becomes textual adventure. "The machine, like man, is captive to language," (73) the narrator notes on his behalf. Some of Alu's musings seem to point to Jakobson's idea of the arbitrariness of the linguistic sign:

"A loom is a dictionaryglossarythesaurus. Why? Words serve no purpose; nothing mechanical." (74)

The very toponymy of the warp and weft is constantly shifting, as do the names of the loom's parts. No surprise then that the resulting meaning is never the result of fixtures but that of everchanging bindings:

"On a loom a beam's name changes after every inch. Why? Every nail has a name, every twist of rope, every little eyelet, every twig of bamboo, every heddle." (74)

Soon the full extent of Alu's différance in conceiving the craft of weaving becomes obvious. Weaving does not just bind the world together, as Balaram had thought. It does more than that: it adds something new to the world, the way only artists can:

"[T]he weaver, in making cloth, makes words, too, and trespassing the territory of the poets gives names to things the eye can't see." (74) 
Thus, like the artists, the weaver has the power to make the invisible visible. At the same time, the loom itself, as textile maker, is saturated with a rich texture of words, defying the lexicon of poetics itslef:

"The loom has given language more words, more metaphor, more idion than all the world's army of pen-wielders." (74).

After having mastered the vocabulary of weaving, Alu can at last sit at the loom, and his progress is prodigious:

"Alu wove still faster. His hands flew like pistons; the shuttle became a wooden blur, its knocking, as it hit the sides of the batten, merged and rose into a whine. Maya marvelled at last; she had never seen such speed...” (75-6)

His productivity grows exponentially.

"Alu learnt quicker than Shombhu Debnath could teach. His loom poured out rainbows of cloth with magic ease." (75)

But soon Alu realizes that his near-industrial output, for all the financial gain that it brought, has led him to an emotional dead-end. $\mathrm{He}$ recalls the narrative that had attracted him to weaving in the first place: the hidden history of Shombhu Debnath's youth elopement from home and his incognito apprenticeship in the closed circle of a clan of virtuoso weavers abroad. And he dreams of Shombhu's legendary weaving,

"Of abrawan muslins as fine as mountain springs, invisible under the surface of the clearest water; shabnam muslins, which when spread on grass melted into the morning dew; cloth which was thin air, fifteen yards of it no heavier than two handfuls of rice, and yet denser than the thickest wool, with four hundred warp threads to the inch. Shameless, shameless insubstantial cloth, nature's mirror, carrying on its conscience the curses of the exiled princess who, swathed in thirty yards of it, had stepped into her father's court, for all the world to see, mother naked and beautiful." (71)

When Shombhu yields at last and starts teaching the Art, his lessons are punctuated by blows, and kicks and stern beatings. When at last, Alu was able to roll out of his loom "six yards covered with the dazzling pointilism of the hundred thousand diamonds, the lokhkhohira-buti" (80) and when he asked for another pattern, another challenge, Shombhu announced flatly that his teaching had come to an end.

"Technique is just the beginning. The world is your challenge now. Look around you and see if your loom can encompass it." (80)

At this point, Alu faces is in the same quandary as any aspiring artist. Now that he masters the technique, he is on his own, as he has to explore the world he means to express. As he begins considering various topics for his 
buti (cloth, tissue), he rules out those that would betray the very material of their expression: bombs, war, hygiene. Some of his concerns are woven directly into the butis, as is his first lovemaking to Maya, that takes place on the shifting warp and weft of the loom itself.

When he tries to take inspiration from the world around him and weaves a 6-yard tapestry of politics, his master rips the cloth apart, treads it underfoot and fumes with anger: "Filth, ... filth; uglier than the man and filthier" and urges the boy to "stop your politics-butis with these elephants and the filth that rides them." (81). Shombhu Debnath's violent rejection of politics reminds us of his response at Balaram's suggestion that the School of Reason will initiate "a new history," when he reacted with disdain: "Whenever people like you start talking about history you can be sure it means nothing but trouble for people like me." (106-107)

The Master's words proved to be foreboding. Politics that secreted out a new history, the history of India's State of Emergency, were to bring a brutal end to Alu's quest for Beauty. As Shombhu Debnath once admitted sorowfully in another prescient monologue:

"You can never learn jamdani because jamdani is dead, with the world which made it. Beauty doesn't exist; it is made like words or forts, by speakers and listeners, warriors and defenders, weavers and wearers. That world has washed away." (81)

\section{The machine that colonized one's heart}

Each character in The Circle of Reason is entranched in their personal obsessions. Their obsessions have started as harmless passtimes, as mere hobbies. Then, in a progression that reminds us of Lawrence Sterne's characters engulfing in the chasm of their own hobby horses, they end up by becoming totally possessed by their passtimes. And, again like in Tristram Shandy, this obsession severs them from all humanity, isolates and insulates them in their private limbo. When he was apparently cured of his obsession with phrenology, Balaram had just swapped his old hobby for two new ones, that were equally all-consuming: weaving as a way to reunite the broken world, and carbolic acid, as a cure-all disinfectant. Alu had too given up language learning for the loom, thus switching from all-encompassing Text to all-binding Textile, both aiming to ecome equally weightless and spiritual.

Even the practical Toru-debi has her own hobby horse, that is, her trusted sewing machine. The Singer machine given to her as part of her dowry is her ideal companion. Indeed, as a young bride "after the trauma of her wedding night" she lives a never-ending "courtship with her machine" (5) that seems to have "securely colonized her heart." (6) 
Indeed, when Alu enters their lives, she shuns taking responsibility, as she sees children as coming from another world, "a world without sewing machines," as they "neither hemmed, nor chain-stitched, nor cross-stitched, nor quilted" (5). Even her phisical outlook is modelled by the machine, her eyes have been "honed into pinpoints of concentration by her years at her sewing machine" (12). Totally engulfed in her sartorial world, Toru-debi is cut out from the real world: "she hardly seemed to recognize the existence of a world outside her sewing room." (13)

And just a few moments before the police was to storm the school and launch the projectile that was to blow up Rakhal's stash of artisanal bombs, killing nearly all the protagonists, Toru-debi had uttered a bizarre sentence: "Only the sewing machine can save us now!" In the hobby-horsical mess that was her mind by now, those words meant that she was stuck in the absurd belief that the real cause of this teachers' war was an overdue order for set of blouses that she was to sew for their enemy's wife.

Out of touch with reality as they might sound, her words pointed at something far more ominous than a mere overdue seamstress work. The paroxistic violence that ends the first section of the book might point actually to an abrupt change in India's politics.

Even if the novel's narator seems to be blisfully oblivious of India's wars and politics, and the novel is eerly lacking in clear historical landmarks, what we do know is that in 1967, Alu was eleven, which means he was born in 1956. He was 14 when he started skipping school (thus in 1970), fifteen when he was apprenticed, and close to sixteen as he was over with advanced weaving. The incident of the airplane crashing onto the school had occured about that time, which might point to the brief IndoPakistani war fought in December 1971 (which is also consistent with the location of the village of Lalkupur, 100 miles North of Calcutta, thus on the pathway of Indian war planes). If we add now the nine months of Parboti's strange pregnancy (strange as the woman claimed to have been impregnated by airplane's erect fuselage), and the 8 to 10 months for her daughter to reach an age where she could be fed solid food, just hours before the disaster, we may conjecture that the Police attack took place in the late spring of 1973.

Historically by the year of 1973 it had become obvious that for India there was "no further growing." (Frank 640) After the drought and poor harvest of 1972, famine, poverty and political unrest dominated the next year. That, alongside with rampant corruption (the Maruti scandal involving Indira's son Rajiv), was to erode what little popular support prime minister Indira Gandhi still enjoyed. By the time the few survivors of the attack had fled - Alu and the weaver master were now targeted as terrorists throughout India - the seed of India's downfall under despotic rule was planted:, "Indira's opponent in the 1971 general election, Raj Narain, filed a petition 
with the Allahabad High Court accusing her of electoral irregularities." (Frank 640) In a few months' time, when the court had ruled against Indira, she fought back by declaring the State of Emergency, that was to suspend many civil rights and instate a tyranical rule. India was falling apart. And maybe indeed "Only the sewing machine can save us now!"

\section{Stitch by stitch}

In a curious move, at the end of its first section, The Circle of Reason not only ditches its original cast of characters, but then moves away from the Indian soil, before the full extent of the Emergency is revealed. Once on Arab territory, weaving and sewing will remain just distant memories, just as torn India will be out of the viewfinder.

That is why we have to turn now to another novel that covers in harrowing detail the drama of the Emergency. A Fine Balance, published in 1995, is the work of Canadian Indian-born Rohinton Mistry, was shortlisted for the Booker Prize and received the Commonwealth Writers' Prize in 1996.

Two of the protagonists of this novel are Ishvar and Omprakash, two tailors, uncle and nephew, who are the sole survivors of the massacre of their families by a tyrannical landlord, who punished them for their protest at electoral irregularities in the village. They fled their devastated homes and are soon engulfed into India's maelstorm of caste prejudice, ethnic hatred, political abuse, administrative bullying, abject poverty and shifting loyalties. Deprived of all goods, owning just a desire to survive, a naive trust in Goodness and the skill of their sewing, they become vagrants, drifting from place to place. They live in dilapidated houses, are turned down by betteroff relatives and eventually end up becoming illegal workers sewing at the service of Dina, a Parsi widow who tries to make a living subcontracting work from a clothing company.

The story advances relentlessly, as if driven by the mere force of entropy, rather than by some divine Providence. It advances slowly, step by step, not unlike the ubiquitous sewing machines - wonder tools of desire and torture racks of drudgery in India - whose minute stitches pace their lives.

Rohinton Mistry lies these lives open before our eyes with the attention to minutae of a surgeon, and the melancholy of a poet. Indeed, this unusally long novel appears at times to have been written by an author of a previous century, Emile Zola maybe. There is no detail of clothing, housing arangement or poor finances of these people that Mistry deems too lowly to be worth mentioning. And yet, amid their day to day concerns and niggles, there is sometimes a ray of hope, that reverberates their raw and frail 
humanity. Such as this moment when Dina, the wounded yet dignified widow, spreads her feelers to the world:

"While her eyes and fingers were immersed in the sewing, she acquired a heightened awareness of noises from flats around her. She collected the sounds, sorted them, replayed them, and created a picture of the lives lived by her neighboursm the way she transformed measurements into clothes." (67-68)

Or as in this moment when Om and Ishvar allow themselves the luxury of daydreaming:

"exhausted by ten hours of sewing, the shared tjhe sanctitity of the hour with the crowd... Soon it would be night... They would weave their plans and dream the future into favourable patterns..." (Mistry 216)

But when the State of Emergency is declared, its ripples was to wreak havoc in the tailors' small world and to dash forever their modest comforts. The two tailors lose their workplace and their home, and then their lives are inextricably entangled with Indira (and Rajiv) Gandhi's vicious schemes at re-engineering the lives of millions of Indians. The Beautification law has them arrested and put in a makeshift ghetto without sanitary facilities in the middle of nowhere, alongside with thousands of jobless dacoits or mere unemployed. A law against Sloth has them interned in a labour camp to break rocks in a quarry, where their health is wasted as the place lacks any basic health services. And as they eventually return to their homeland with the hope to find a wife for Om, they have a run-in with the law of Birth Control; they are rounded up by the police along with every male in the marketplace and then they are forcibly sterilized. Then, in the end, in 1984, nine years after the Emergency, the death of Indira Gandhy by the hands of her own guard brings no relief, as the two tailors are now broken men, jobless, just shells of their former selves.

\section{Another patch in the quilt}

Is there any sort of redemption, of reprieve from the claws of History in this long depressing tale? Apparently not. And yet, if we look closer, there are moments when all these chance encounters, these random disappearances, these haphazard acts of state violence and these instances of arbitrary suffering seem to align themsleves into patterns that begin to make some sense.

And what is interesting, these have to do with cloth and cloth-making again. But not with the mechanical stitching and sewing that had dotted these small lives. Not with lucrative sewing, but with its playful, whimsical and arbitrary variant: quilting. 
Making a quilt out of patches is an innocent passtime for Dina, who used to collect scraps of cloth without any apparent purpose. The raw material for a quilt consists of scraps and bits of unwanted material. Not unlike the lives of the common people might appear to the eyes of Nanny State government, who claims there is no proper use for them.

It is only towards the end of the novel that the deeper meaning of her work becomes apparent. The character that is the first to suggest a deeper meaning to the quilt is Manech, the student.

"I prefer to think of God as a giant quiltmaker. With an infinite variety of designs. And the quilt is grown so big an confusing, the pattern is impossible to see, the squares and diamonds and triangles don't fit well together anymore, it's all become meaningless." (413)

The student's nihilism might seem to apply to the haphazard nature of the novel's encounters and incidents, that seem to defy any attempt at distinguishing a pattern. Indeed, in his quest for realism, Mistry avoids any easy temptation to align events in meaningful patterns, the same way he resists melodramatic or sensationalist exploitation.

It is Manech, with his intellectual background, who has more difficulty piecing the scraps of his life together. Sometimes it is the mere touching those cloth scraps that causes the epiphany:

"His joy went out like a lamp. The future was becoming past. Everything vanished into the void, and reaching back to grasp for something, everything vanished into the void, and reaching back to grasp - what? A bit of string, scraps of cloth, shadows of the golden time. (Mistry 597)

Unlike Manech, Dina and the tailors, even when they feel that "the stitches were broken," alternate between melancholy and hope, as the "tent of time [was] sagging one moment, billowing the next." (595) When Om suggests that they should "try this game with the quilt," they use the patchwork as a mnemonic device:

"He and Maneck located the oldest piece of fabric, and moved chronologically, patch by patch, reconstructing the chain of mishaps and triumphs, till they reached the uncompleted corner." (594)

And when they reach a patch related to a catastrophic moment of their past (when their house was demolished by the government), Dina's impulse is to take the scissors, cut that patch out and annihilate the memory, as it were. Ishvar rejects this emotional approach, as "his fingers stroked the cambric texture, recapturing the time" (596) and declares that the past events, once memorialized, can no longer be contemplated in themselves, but only in conjunction. Ishvar wisely declares that "calling one piece sad is meaningless" as it might be connected to a "happy piece" like "sleeping on a verandah" or to that "violet tusser when we made masala wada and started 
cooking together." (Mistry 596-7). Ishvar is the first that is able to get a bird's eye view on their interconnecting lives and to contemplate them as a variegated artwork, a tapestry of contrasting colours, rather than a series of blows and rebounds, of traumas and dashed hopes.

Ishvar can now see that their lives only make sense against the background of this larger canvas, and that it is not the length of objective time that they should consider, but rather the way time conspired to bring their destinies together.

"Time [said Ishvar] is without length or breadth. The question is what happened during its passing. And what happened is, our lives were joined together."

"Like these patches," said Om. (598)

With this newly acquired understanding of life, even the disasters brought about the characters' lives by a despotic government appear to be outrun by the action of individual destinies coming together to form the bigger picture of a gigantic quilt.

And thus, when the goondas, the thugs of the landlord, descend upon Dina to forcibly evict her from her house, ignoring her court appeal, snubbing at the laws and testimony and evidence as "those stupid things [that] are unnecessary under the Emergency," Dina is still able to brace herself up for the unavoidable and to summon a philosophical conclusion:

"One phase of life was concluding, another beginning. Time for the latest installment, she thought. Another patch in the quilt." (690)

\section{Reference list}

Ferber, Michael. "Weaving and Spinning". Dictionary of Literary Symbols. Cambridge UP 1999, pp. 228-231

Frank, Katherine. Indira: The Life of Indira Nehru Gandhi. eBook. London: Harper Collins, 2001.

Ghosh, Amitav. The Circle of Reason. Abacus, 1991 [original edition 1986, Hamish Hamilton].

Machado, Pedro and Sarah Fee. "Introduction: The Ocean's Many Cloth Pathways". Textile Trades, Consumer Cultures, and the Material Worlds of the Indian Ocean, Palgrave Studies in Indian Ocean Eorld Cultures, Palgrave 2018, pp. 1-25.

Mistry, Rohinton. A Fine Balance. Toronto: McClelland \& Steward, 1995.

Presdtholt, Jeremy. "The Fabric of the Indian Ocean World: Refections on the Life Cycle of Cloth." Textile Trades, Consumer Cultures, and the Material 
Worlds of the Indian Ocean, Palgrave Studies in Indian Ocean World Cultures, Palgrave 2018, pp. 385-396

Ray, Himanshu Prabha. "Warp and Weft: Producing, Trading and Consuming Indian Textiles Across the Seas (First-Thirteenth Centuries CE)", Textile Trades, Consumer Cultures, and the Material Worlds of the Indian Ocean, Palgrave Studies in Indian Ocean World Cultures, Palgrave 2018, pp. 289311.

Subramanian, Lakshmi. "Cloth and Commerce; Understanding Indian Economic Hisotry." P. Machado et al. (eds.) Textile Trades, Consumer Cultures, and the Material Worlds of the Indian Ocean, Palgrave Studies in Indian Ocean World Cultures, Palgrave 2018, pp. 55-77. 